\title{
COMPARISION OF BUILDING FOR SESMIC RESPONSE BY USING BASE ISOLATION
}

\author{
Sonali Anilduke', Amay Khedikar ${ }^{2}$ \\ ${ }^{I}$ Tulsiramji Gaikwad Patil College of Engineering and Technology ${ }^{I}$, RTMNU, Nagpur University, Nagpur \\ ${ }^{2}$ Asst. Prof Tulsiramji Gaikwad Patil College of Engineering and Technology ${ }^{2}, R T M N U$, Nagpur University, Nagpur
}

\begin{abstract}
Throughout historic time Earthquakes are one of the natural hazards that occur due to sudden violent movement of earth's surface which causes damage to property, especially to man-made structures. Base isolation is one of the most powerful tools of earthquake engineering pertaining to the passive structural vibration control technologies. The application of the base isolation techniques to protect structures against damage from earthquake attacks has been considered as one of the most effective approaches and has gained increasing acceptance during the last two decades. This paper present three dimensional nonlinear time history analysis is performed on r/c building by the use of computer program SAP 2000 v12.0.0. The dynamic analysis of the structure has been carried out and the performance of the building with and without isolator is studied. The main objective here is to make seismic response control by providing Isolators and comparing between the fixed based and isolated base building. Rubber bearing and Friction pendulum bearing are used
\end{abstract}

Keywords: Base Isolation; Seismic Response; Time History

\section{INTRODUCTION}

Seismic base isolation is a well-defined building protection system against earthquakes. Earthquakes are one of nature greatest hazards; throughout historic time they have caused significant loss of life and severe damage to property, especially to man-made structures. On the other hand, earthquakes provide architects and engineers with a number of important design criteria foreign to the normal design process. Seismic isolation is a structural design approach that aims to control the response of a structure to horizontal ground motion through the installation of a horizontally flexible and vertically stiff layer of structural isolation hardware between the superstructure and its substructure. The dynamics of the structure is thus changed such that the fundamental vibration period of the isolated structural system is significantly longer than that of the original, nonisolated structure, leading to a significant reduction in the accelerations and forces transmitted to the isolated structure and significant displacements in the deformable, structural base isolation, layer.

Time History Method shall be used on as approximate ground motion and shall be performed by using accepted principles of Dynamics. Response Spectrum Method of analysis shall be performed by using design spectrum specified in 6.4.2 as per I.S. 1893(Part1):2002

$* * *$

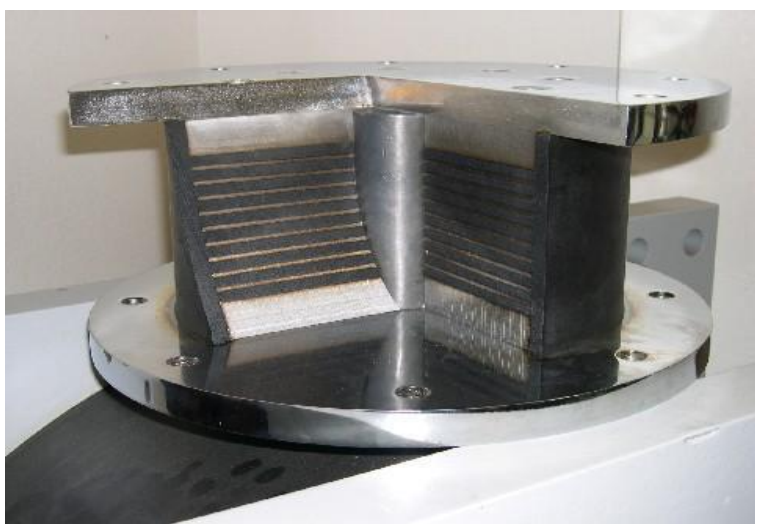

Fig.1 C/S of Lead Rubber Bearing

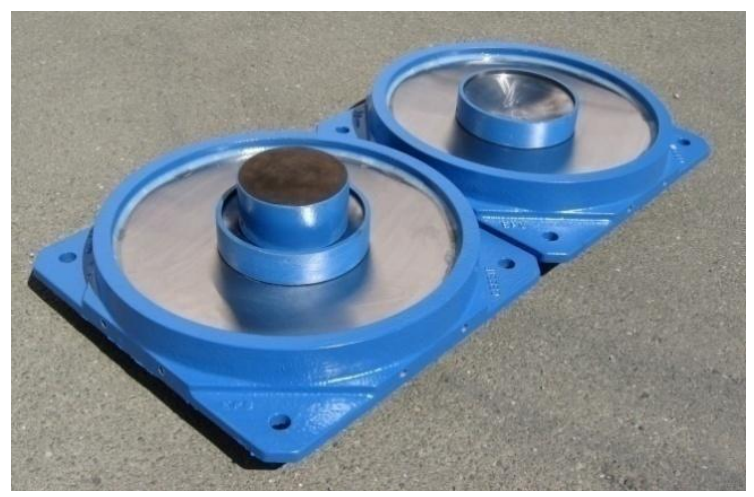

Fig.2 Friction Pendulum Bearing

\subsection{Concept of Base Isolation}

The basic concept of base isolation is to protect the structure from the damaging effects of an earthquake by improving dynamic response of structure. When base isolation is used, special bearings are installed between the bottom of the 
building and its foundation. The bearings are flexible in the horizontal direction and reduce the natural frequency of a building. The first dynamic mode of the isolated structure involves deformation only in the isolation system, and the structure above remains almost rigid. An isolated system does not absorb the vibrating energy, but rather deflects it through the dynamics of the system. It lengthens the natural period of vibration of the structure so that the responses are greatly reduced. In some cases a passive damper may also use to control excessive displacement. Figure 3 represents the shifting of period by the isolator and the resulting reduction in the acceleration response.

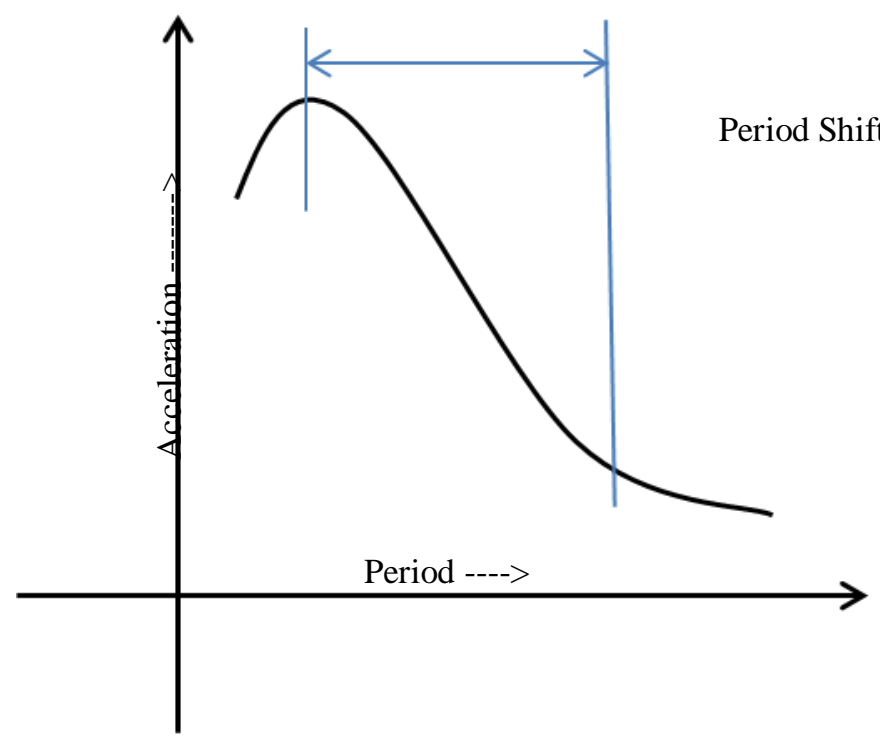

Fig 3 Period shift induced by an isolator

The main objective of this work is

- To illustrate the basic concept and behavior of the base isolated structures.

- $\quad$ To Analyze a building by providing rubber bearing and friction pendulum bearing.

- To study and compare total base shear force, maximum absolute acceleration, velocity ,displacement with respect to the fixed base and isolated base structure.

\section{DETAIL EXPERIMENTAL}

For comparing a fixed base and isolated base building a Seven-storied building is modeled in the SAP 2000 software . An open frame building model with3 and 4 bays in each $X$ and $\mathrm{Y}$ directions, the height of each storey as $3.2 \mathrm{~m}$ are modeled. Height .of building is $22.4 \mathrm{~m}$, Width of building in $\mathrm{X}$ direction is $11 \mathrm{~m}$ and Width of building in $\mathrm{Y}$ direction is $14 \mathrm{~m}$. The material properties of the frame elements and the area element are defined and M25 concrete grade and Fe415 is used. The rebar material properties are also given. The beams and columns of dimensions b1 300x300,b2 $300 \times 350, \mathrm{c} 1230 \times 350, \mathrm{c} 2230 \times 400, \mathrm{c} 3230 \times 450 \mathrm{~mm}$ are given as frame elements. The slab in the building is assigned as a shell element with a thickness of $120 \mathrm{~mm}$. Live load is taken as $3 \mathrm{kn} / \mathrm{m} 2$.Interior and Exterior wall thickness is taken as $150 \mathrm{~mm}$ and $230 \mathrm{~mm}$. Soil type is taken as 1 ,Zone factor is $\mathrm{V}$, Response reduction factor is taken as 5.And Importance factor is 1 .. The support condition at the bottom is made as fixed and the fixed-base analysis is performed considering the combination of $1.5(\mathrm{DL}+\mathrm{LL})$. All other data is referred from I.S.1893-2002. The period for the fixed base is identified. Then the calculated rubber properties are given as link/ support properties in the software and the baseisolation model analysis is performed. The response of the structure with the rubber isolator and friction pendulum isolators are determined. The parameters selected to define the utilized Isolators in the SAP2000 program are as follows:

ForRubber Bearing: Nonlinear Link Type: Rubber, U1 Linear Effective Stiffness: $1500000 \mathrm{kN} / \mathrm{m}$, U2 and U3 Linear Effective Stiffness: $800 \mathrm{kN} / \mathrm{m}$, U2 and U3 Nonlinear Stiffness : $2500 \mathrm{kN} / \mathrm{m}, \mathrm{U} 2$ and U3 Yield Strength : $80 \mathrm{kN}$, U2 and U3 Post Yield Stiffness Ratio: 0,1.For Friction Pendulum Bearing: Nonlinear Link Type: Friction Isolator, U1 Linear Effective Stiffness: $15000000 \mathrm{kN} / \mathrm{m}$, U1 Nonlinear Effective Stiffness: $15000000 \mathrm{kN} / \mathrm{m}$, U2 and U3 Linear Effective Stiffness: $750 \mathrm{kN} / \mathrm{m}$, U2 and U3 Nonlinear Stiffness: $15000 \mathrm{kN} / \mathrm{m}$, U2 and U3 Friction Coefficient, Slow: 0,03,U2 and U3Friction coefficient, Fast : 0,05, U2 and U3 Rate Parameter: 40, U2 and U3 Radius of Sliding Surface: 2,23.(Referred from. Torunbalcil and G. Ozpalanlar2 octo.12-17(2008))

\section{RESULTS AND DISCUSSION}

Analysis is done for both $\mathrm{X}$ and $\mathrm{Y}$ direction for fixed base and isolated base and is also carried for different storey heights of the building for the same building plan i.e. each floor. The isolator in each case varies in its total height and its single layer thickness depends on the vertical loads on the columns. The corresponding increase in time verses displacement by using time history analysis is done. represented by graph for fixed, rubber and friction beraring base fig. $4 a, 4 b, 4 c$ in $X$ and $5 a, 5 b, 5 c$ Y direction.

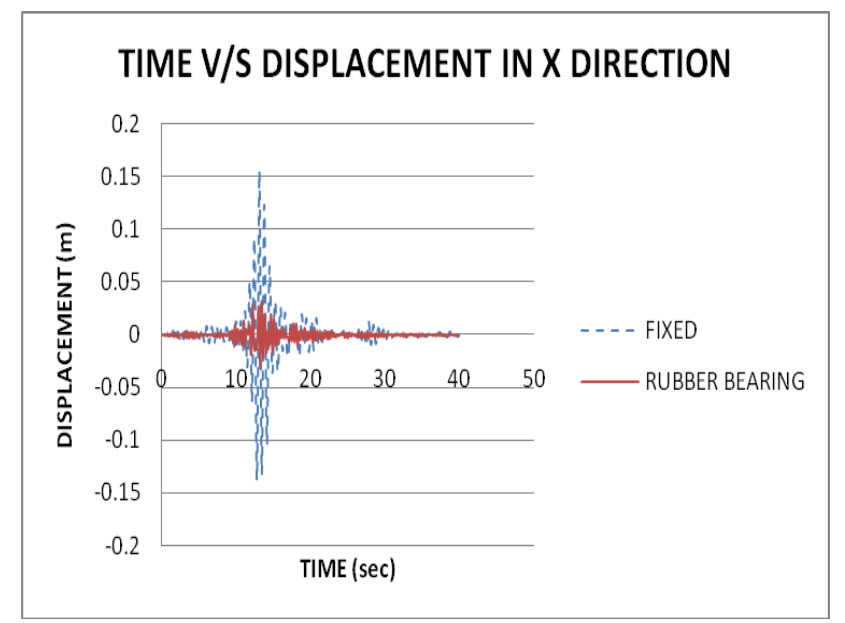

Fig 4a. For Fixed and Rubber bearing 


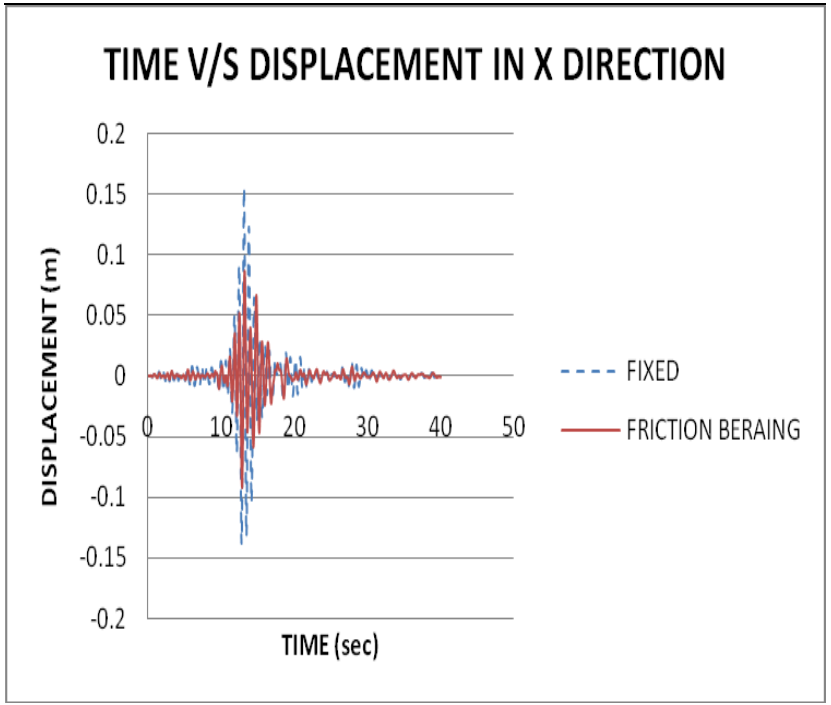

Fig 4b. For Fixed and Friction bearing

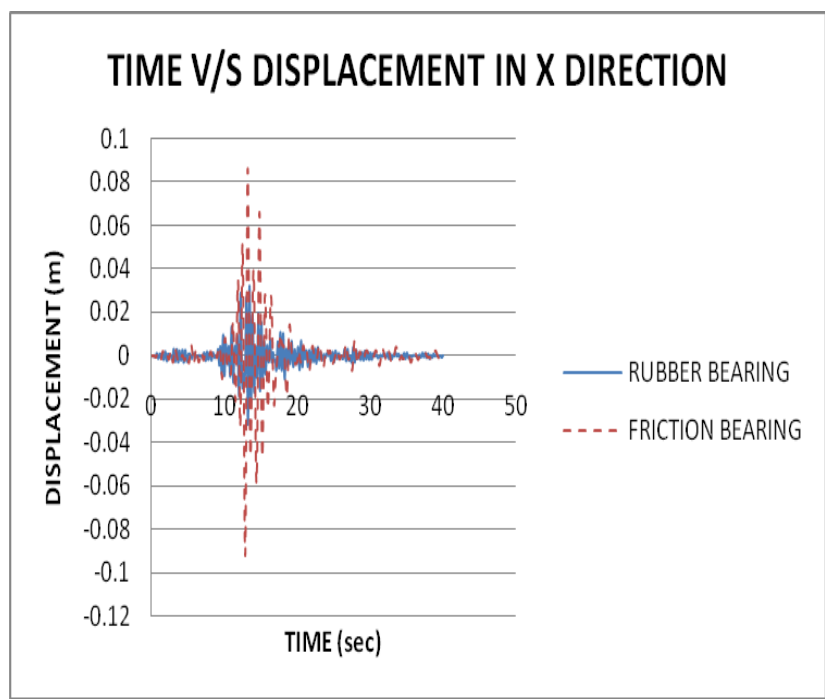

Fig 4c. For Friction and Rubber bearing

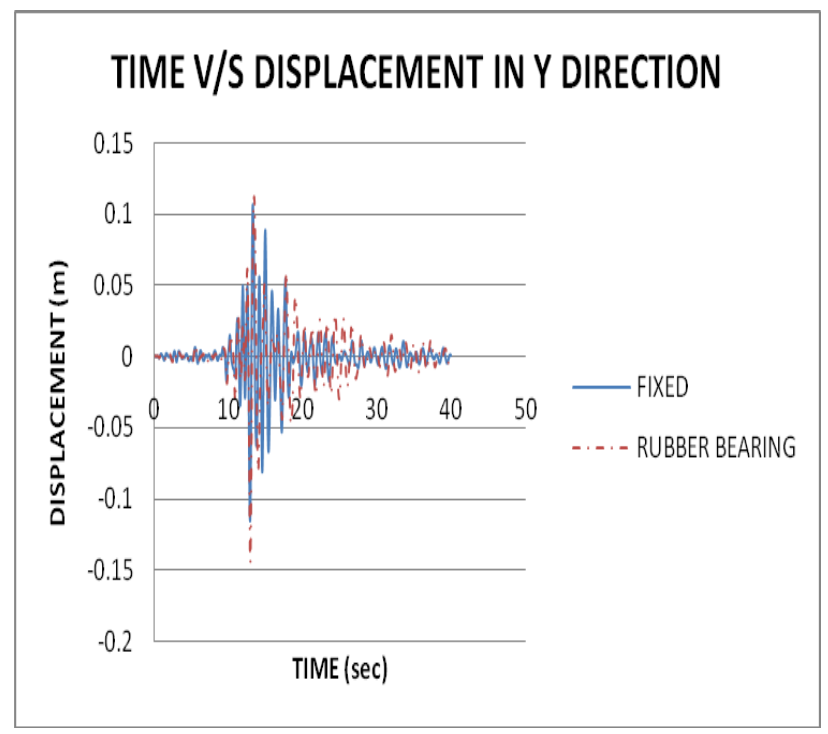

Fig 5a. For Fixed and Rubber bearing

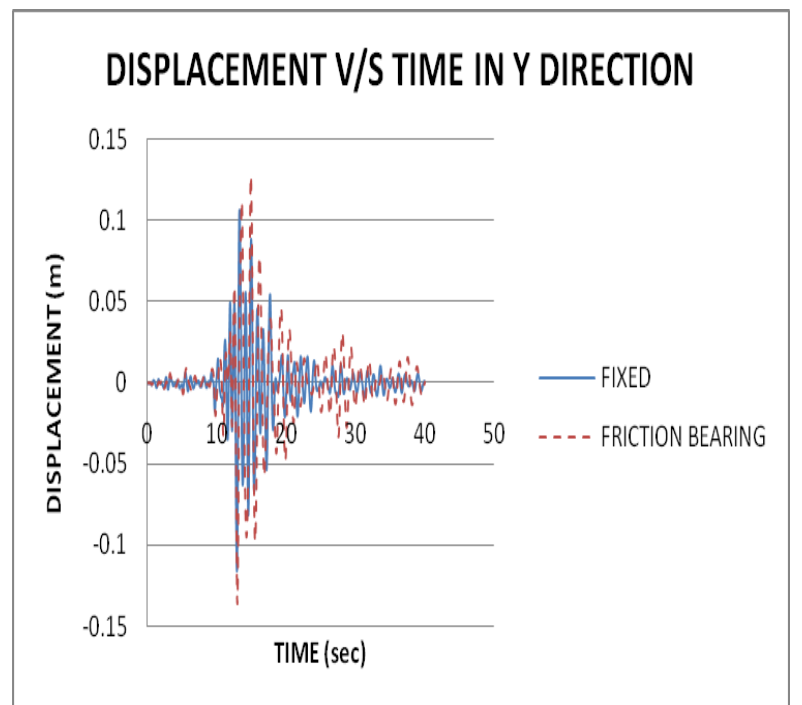

Fig 5 b. For Fixed and Friction bearing

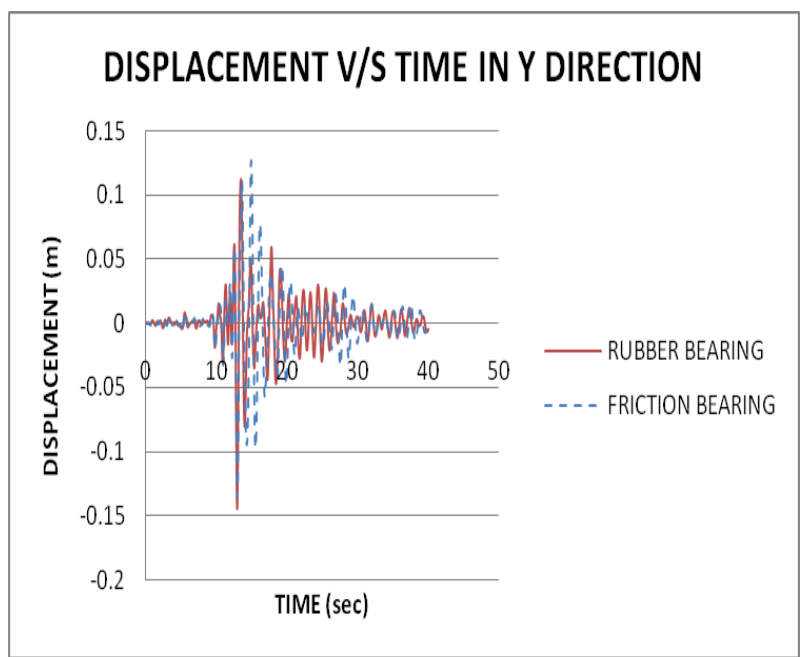

Fig 5c. For Friction and Rubber bearing

Base reaction in $\mathrm{X}$ and $\mathrm{Y}$ direction for Fixed base ,Rubber bearing and friction bearing isolators are represented byfig. 6 and values are shown in table 1

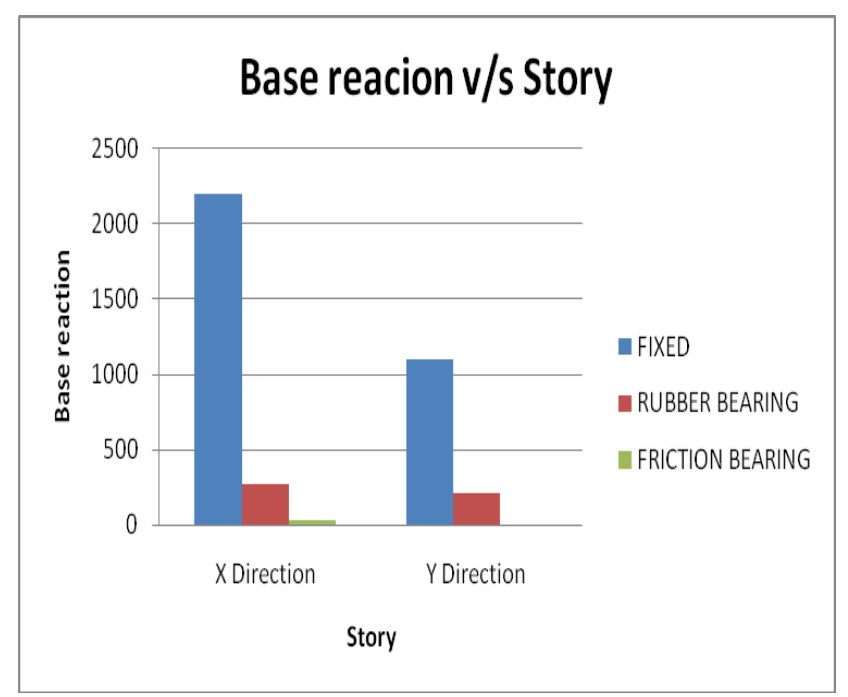

Fig 6. Base reaction v/s Story in $\mathrm{X}$ and $\mathrm{Y}$ direction 
Table 1.Base Reaction

\begin{tabular}{|c|c|c|c|}
\hline & FIXED & RB & FRB \\
\hline X-Direction & 2200.176 & 268.558 & 33.616 \\
\hline Y-Direction & 1099.898 & 214.554 & 5.837 \\
\hline
\end{tabular}

Displacement with respect to story for fixed base ,rubber beraring, friction bearing are represented by fig 7 a for $\mathrm{X}$ direction and $7 \mathrm{~b}$ for $\mathrm{Y}$ direction and values are shown in table 2

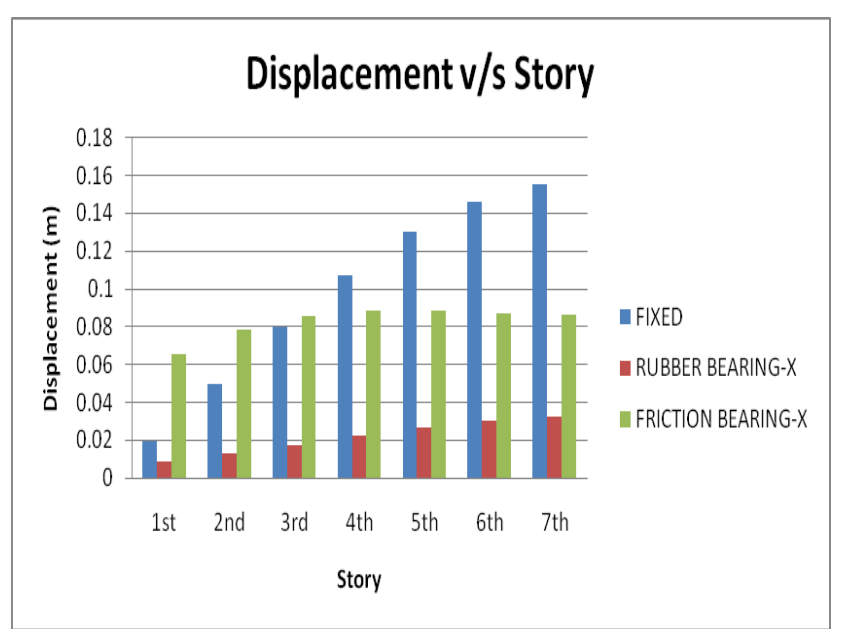

Fig 7a. Displacement v/s Story in X direction

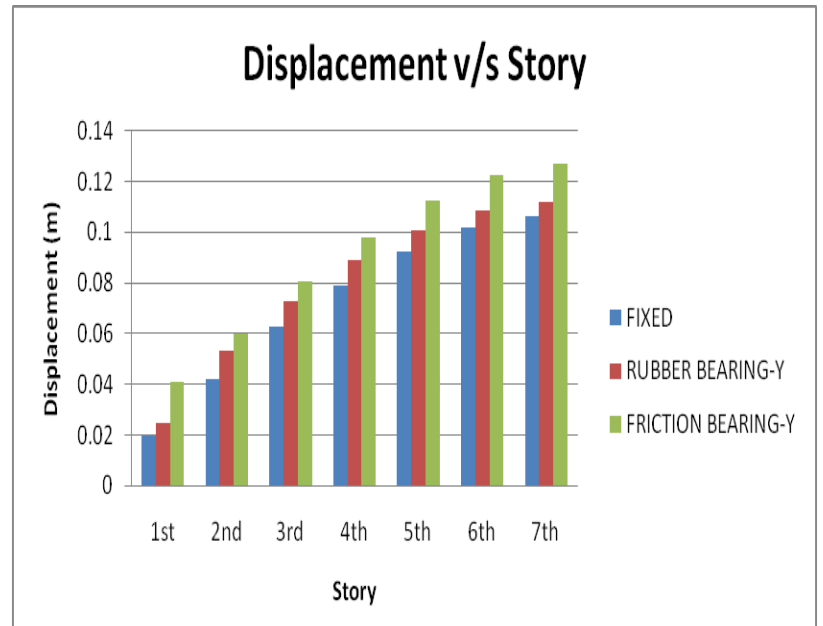

Fig 7b. Displacement v/s Story in Y direction

Table 2

\begin{tabular}{|c|c|c|c|c|c|c|}
\hline & \multicolumn{6}{|c|}{ JOINT DISPLACEMENT } \\
\hline & $\begin{array}{c}\text { Fixed } \\
\mathrm{U} 1\end{array}$ & $\begin{array}{c}\text { Fixed } \\
\mathrm{U} 1\end{array}$ & $\begin{array}{c}\mathrm{RB} \\
\mathrm{U} 1\end{array}$ & $\begin{array}{c}\mathrm{RB} \\
\mathrm{U} 2\end{array}$ & $\begin{array}{c}\text { FRB } \\
\mathrm{U} 1\end{array}$ & $\begin{array}{c}\text { FRB } \\
\mathrm{U} 2\end{array}$ \\
\hline $\begin{array}{c}\text { Store } \\
\mathrm{y}\end{array}$ & $\mathrm{X}$ & $\mathrm{Y}$ & $\mathrm{X}$ & $\mathrm{Y}$ & $\mathrm{X}$ & $\mathrm{Y}$ \\
\hline & $\mathrm{m}$ & $\mathrm{m}$ & $\mathrm{m}$ & $\mathrm{m}$ & $\mathrm{m}$ & $\mathrm{m}$ \\
\hline 1st & $\begin{array}{c}0.0196 \\
9\end{array}$ & $\begin{array}{c}0.019 \\
4\end{array}$ & $\begin{array}{c}0.008 \\
6\end{array}$ & $\begin{array}{c}0.024 \\
8\end{array}$ & $\begin{array}{c}0.0657 \\
3\end{array}$ & $\begin{array}{c}0.0410 \\
5\end{array}$ \\
\hline 2nd & $\begin{array}{c}0.0498 \\
1\end{array}$ & $\begin{array}{c}0.042 \\
2\end{array}$ & $\begin{array}{c}0.012 \\
6\end{array}$ & $\begin{array}{c}0.052 \\
9\end{array}$ & $\begin{array}{c}0.0783 \\
2\end{array}$ & $\begin{array}{c}0.0596 \\
8\end{array}$ \\
\hline 3rd & $\begin{array}{c}0.0800 \\
6\end{array}$ & $\begin{array}{c}0.062 \\
5\end{array}$ & $\begin{array}{c}0.017 \\
3\end{array}$ & 0.073 & $\begin{array}{c}0.0857 \\
9\end{array}$ & $\begin{array}{c}0.0804 \\
9\end{array}$ \\
\hline 4th & 0.0107 & 0.079 & 0.022 & 0.089 & 0.0887 & 0.0979 \\
\hline
\end{tabular}

\begin{tabular}{|c|c|c|c|c|c|c|}
\hline & 54 & 2 & 2 & 3 & 2 & 2 \\
\hline 5th & 0.1302 & $\begin{array}{c}0.092 \\
4\end{array}$ & $\begin{array}{c}0.026 \\
7\end{array}$ & $\begin{array}{c}0.100 \\
7\end{array}$ & $\begin{array}{c}0.0886 \\
3\end{array}$ & $\begin{array}{c}0.1124 \\
9\end{array}$ \\
\hline 6th & $\begin{array}{c}0.1464 \\
1\end{array}$ & $\begin{array}{c}0.101 \\
7\end{array}$ & $\begin{array}{c}0.030 \\
2\end{array}$ & $\begin{array}{c}0.108 \\
4\end{array}$ & $\begin{array}{c}0.0873 \\
4\end{array}$ & 0.1225 \\
\hline 7th & $\begin{array}{c}0.1555 \\
8\end{array}$ & $\begin{array}{c}0.106 \\
7\end{array}$ & $\begin{array}{c}0.032 \\
2\end{array}$ & 0.112 & $\begin{array}{c}0.0863 \\
2\end{array}$ & $\begin{array}{c}0.1273 \\
4\end{array}$ \\
\hline
\end{tabular}

Acceleration with respect to story for fixed base ,rubber bearing, friction bearing are represented by fig 8 a for $\mathrm{X}$ direction and $8 \mathrm{~b}$ for $\mathrm{Y}$ direction and values are shown in table 3

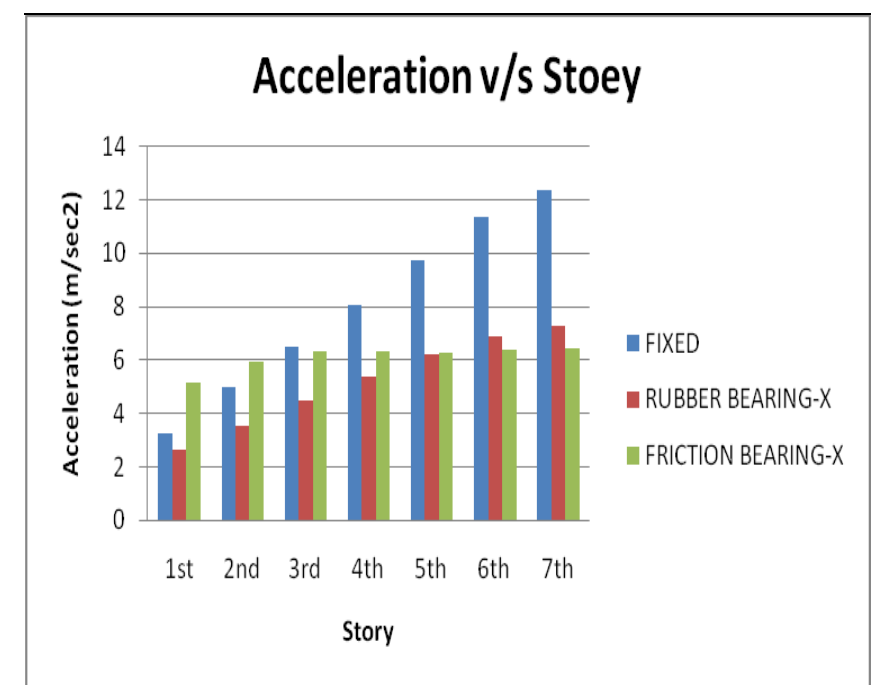

Fig 8a. Acceleration v/s Story in X direction

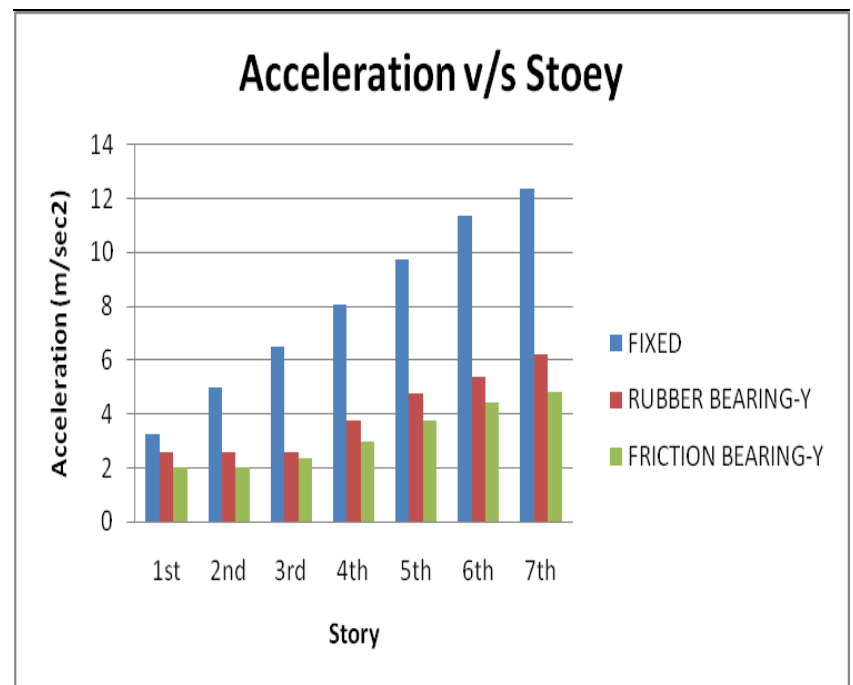

Fig 8b. Acceleration v/s Story in Y direction

Table 3

\begin{tabular}{|c|c|c|c|c|c|c|}
\hline & \multicolumn{6}{|c|}{ JOINT ACCELERATION } \\
\hline & $\begin{array}{c}\text { Fixed } \\
\mathrm{U} 1\end{array}$ & $\begin{array}{c}\text { Fixed } \\
\mathrm{U} 1\end{array}$ & $\begin{array}{c}\mathrm{RB} \\
\mathrm{U} 1\end{array}$ & $\begin{array}{c}\mathrm{RB} \\
\mathrm{U} 2\end{array}$ & $\begin{array}{c}\text { FRB } \\
\mathrm{U} 1\end{array}$ & $\begin{array}{c}\text { FRB } \\
\mathrm{U} 2\end{array}$ \\
\hline $\begin{array}{c}\text { Store } \\
\mathrm{y}\end{array}$ & $\mathrm{X}$ & $\mathrm{Y}$ & $\mathrm{X}$ & $\mathrm{Y}$ & $\mathrm{X}$ & $\mathrm{Y}$ \\
\hline & $\begin{array}{c}\mathrm{m} / \mathrm{sec} \\
2\end{array}$ & $\begin{array}{c}\mathrm{m} / \mathrm{sec} \\
2\end{array}$ & $\begin{array}{c}\mathrm{m} / \mathrm{sec} \\
2\end{array}$ & $\begin{array}{c}\mathrm{m} / \mathrm{sec} \\
2\end{array}$ & $\begin{array}{c}\mathrm{m} / \mathrm{sec} \\
2\end{array}$ & $\mathrm{~m} / \mathrm{sec}^{2}$ \\
\hline
\end{tabular}




\begin{tabular}{|c|c|c|c|c|c|c|}
\hline 1st & 3.268 & 2.474 & 2.644 & 2.588 & 5.124 & 2.013 \\
\hline 2nd & 4.982 & 2.647 & 3.507 & 2.557 & 5.947 & 1.989 \\
\hline 3rd & 6.523 & 3.877 & 4.452 & 2.577 & 6.330 & 2.346 \\
\hline 4th & 8.073 & 4.785 & 5.398 & 3.747 & 6.341 & 2.982 \\
\hline 5th & $\begin{array}{c}9.738 \\
5.13\end{array}$ & 6.243 & 4.773 & 6.250 & 3.739 \\
\hline 6th & $\begin{array}{c}11.36 \\
9\end{array}$ & 5.138 & 6.885 & 5.400 & 6.362 & 4.405 \\
\hline 7th & $\begin{array}{c}12.37 \\
6\end{array}$ & 5.421 & 7.257 & 6.221 & 6.433 & 4.802 \\
\hline
\end{tabular}

[8] S.J.Patil, G.R.Reddy "State Of Art Review - Base Isolation Systems For Structures" International Journal of Emerging Technology and Advanced Engineering Volume 2, Issue 7, (July 2012)

[9] S.Keerthana1, K. Sathish Kumar2, K. Balamonica3, D.S.Jagannathan4"Seismic Response Control Using Base Isolation Strategy "International Conference on Advances in Civil Engineering and Chemistry of Innovative Materials (ACECIM'14) Volume 4, Special Issue 4, June 2014

\section{CONCLUSION}

[10] Chauhan Kalpesh M.1, Dr.B.J.Shah2” EXCEL SPREADSHEET FOR DESIGN OF LEAD RUBBER BEARING USES FOR SEISMIC ISOLATION OF BRIDGES" Chauhan et al, International Journal of Advanced Engineering Research and Studies , IJAERS/Vol. II/ Issue III/April-June, 2013/60-62

Isolators controls structural response in which the building or structure is decoupled from the horizontal component of the earthquake ground motion. A base-isolation system reduces ductility demands on a building, and minimizes its deformations. From the result, By conducting the nonlinear time history analysis it was shown that base isolation increases the flexibility at the base of the structure which helps in energy dissipation due to the horizontal component of the earthquake and hence superstructure's seismic demand drastically reduced as compared to the conventional fixed base structure.

\section{REFERENCES}

[1] Y. Ribakov and I. Iskhakov," Experimental Methods for Selecting Base Isolation Parameters for Public Buildings ." The Open Construction and Building Technology Journal, 2008, 2, 1-6 (2008).

[2] Dinu Bratosin "Non linear effects in seismic base isolation." Proceedings of the Romanian academy, Series A, Volume 5, Number 3/2004, pp.(2004)

[3] Jemes K Kelly "The implementation of base isolation in the United States" earthquake engg tenth world conference 1994 Balkema, Rotterdam ISBN0954100605 (1994)

[4] Young-sang kim "Study on effective stiffness of base isolation system for reducing acceleration and displacement responses." Journal of the Korean nuclear society volume 31, number 6, pp.586-594, (Dec1999)

[5] A. B. M. Saiful Islam*, Mohammed Jameel and Mohd Zamin Jumaat "Seismic isolation in buildings to be a practical reality: Behavior of structure and installation technique." Journal of Engineering and Technology Research Vol. 3(4), pp. 99-117, (April 2011)

[6] Gordon P. Warn, and Keri L. Ryan "A Review of Seismic Isolation for Buildings: Historical Development and Research Needs" Department of Civil and Environmental Engineering, Pennsylvania State University, 226B Sackett Building, University Park, PA 16802, USA (Aug2012)

[7] Hossein Monfared, Ayoub Shirvani, Sunny Nwaubani "An investigation into the seismic base isolation from practical perspective" Internationals journal of civil and structural engineering Volume 3, No 3 (2013)

[11] Chandak N. R." Effect of Base Isolation on the Response of Reinforced Concrete Building" Journal of Civil Engineering Research 2013

[12] T. Subramani1, J. Jothi 2, M. Kavitha3" Earthquake Analysis of Structure by Base Isolation Technique in SAP" T. Subramani et al Int. Journal of Engineering Research and Applications ISSN : 2248-9622, Vol. 4, Issue 6( Version 5), June 2014, pp.296-305

[13] Won-Kee Hong *, Hee-Cheul Kim" Performance of a multi-story structure with a resilient-friction base isolation system" Department of Architectural and Civil Engineering, Kyung Hee University, Kyungkido 449-701, Korea (7 June 2004)

[14] N. Torunbalci1 and G. Ozpalanlar2" Earthquake Response Analysis of Mid -Story Buildings isolated with various Seismic Isolation Techniques" The 14th World Conference on Earthquake Engineering October 12-17, 2008, Beijing, China

[15] E. Blandford, E. Keldrauk, M. Laufer, M. Mieler, J. Wei, B. Stojadinovic, and P.F. Peterson" Advanced Seismic Base Isolation Method For Modular Reactors" Departments of Civil and Environmental Engineering and Nuclear Engineering University of California Berkeley, California September 30, 2009

[16] By Lin Su,1 Goodarz Ahmadi,2 and Iradj G. Tadjbakhsh3" Comparative Study of Base Isolation Systems" 